\title{
Fibrosis of the Quadriceps Muscles Secondary to Sickle Cell Disease: A Case Report
}

\author{
Timothy 0. Awotunde1, Samuel Uwale Eyesan ${ }^{1 *}$, Samuel Adesope Adesina ${ }^{1}$, \\ Babajide Oladayo Ayandele', G. H. Ano Edward ${ }^{2}$ \\ ${ }^{1}$ Department of Orthopeadic Surgery, Bowen University Teaching Hospital, Ogbomoso, Nigeria \\ ${ }^{2}$ Department of Histopathology, Bowen University Teaching Hospital, Ogbomoso, Nigeria \\ Email: *uwale_eyesan@yahoo.com
}

How to cite this paper: Awotunde, T.O., Eyesan, S.U., Adesina, S.A., Ayandele, B.O. and Ano Edward, G.H. (2016) Fibrosis of the Quadriceps Muscles Secondary to Sickle Cell Disease: A Case Report. Open Journal of Orthopedics, 6, 326-329.

http://dx.doi.org/10.4236/ojo.2016.610043

Received: June 13, 2016

Accepted: October 18, 2016

Published: October 21, 2016

Copyright $\odot 2016$ by authors and Scientific Research Publishing Inc. This work is licensed under the Creative Commons Attribution International

License (CC BY 4.0).

http://creativecommons.org/licenses/by/4.0/

\begin{abstract}
The musculo-skeletal system is commonly affected in sickle cell disease, manifesting itself as bone infarction, femoral head osteonecrosis, osteomyelitis, myonecrosis, myofibrosis and fascitis. Myositis and fasciitis are observed during a vaso-occlusive crisis in $4 \%$ of patients. Pain and swelling of bilateral proximal groups of muscles of upper and lower limbs are common presenting complaints due to prolonged sickling crises [1]. We report a case of 30-year old known HbSS patient with bilateral knee stiffness of two months duration, with associated swelling and warmth of both thighs. No preceding history of trauma. He was said to suffer at least two sickling crises in a month with the last one occurring one week prior to presentation. X-ray of the thigh showed no calcification in muscle groups. He was commenced on flexionextension exercises.
\end{abstract}

\section{Keywords}

Fibrosis of Quadriceps Muscle, Sickle Cell Disease

\section{Introduction}

While complications of sickle cell disease such as arthropathy, chronic leg ulcer, and osteomyelitis are frequently seen and reported, medical literature on muscular complications of sickle cell aneamia is scanty due to their infrequent occurrence.

Thirteen cases have been reported so far in literature [1]. Risk factors include frequent intramusclar injections, frequent pain crises misdiagnosed as bone paincrisis in addition to stress, cold temperatures, drinking large amounts of alcohol, infection and dehydration as a result of the kidneys' inability to conserve water [1]. It is caused by any condition that increases plasma viscosity which delays the passage of the sickled 
cells through the capillaries, producing an increase in sickling and a vicious cycle of venous stasis, further sickling, capillary congestion, and infarction [2]. Furthermore, Nitric Oxide (NO), an endothelium derived relaxation factor that mediates vasodilation in a dependent manner to counter the processes induced by hypoxia, is in short supply in sickle cell disease because it is limited by superoxide anions $\left(\mathrm{O}_{2}^{-}\right)[3]$.

It presents with pain and swelling of bilateral proximal groups of muscles of upper and lower limbs. Untreated, it can lead to muscular atrophy and contracture with significant functional impairment [4].

Investigations include determination of serum CPK and LDH levels and MRI.

However, muscle biopsy is the gold standard [5].

Treatment includes the standard therapy for sickle cell crisis and application of warm soaks to the affected muscles for pain relief with gradual resolution within 2 - 4 weeks, and surgical fascotomy or incision and drainage to relieve areas of localized, tight swelling [6].

This work will help raise the awareness of myofibrosis as a possible, though rare, complication in sicklers so health care workers may avoid unnecessary interventions such as frequent intramuscular injections which may worsen prognosis, and refer in time to appropriate quaters to avoid its disabling sequelae.

\section{Case Report}

We evaluated a 30-year old male known HbSS patient with bilateral knee stiffness of two months duration prior to presentation. There was associated history of swelling and warmth at both thighs. No preceding history of trauma to the knee or the thigh.

There was however a positive history of fever, low grade with chills three days prior to presentation.

No history of cough, catarrh, dysuria or passage of loose watery stool. On examination, he was chronically ill-looking, pale, with a tinge of jaundice, and well hydrated.

Both knee joints were swollen and tender with differential warmth. No area of flunctuance.

There was patchy hyperpigmentation more on lateral aspects of both thighs with significant hardening of the muscles of the anterior and lateral aspects of the thigh, worse on the left. No tenderness. And no previous history of I. M injections to the thigh.

He also had bilateral chronic leg ulcer which was subsequently grafted with a good take.

Flexion of the knee was 100 both active and passive.

$\mathrm{X}$-ray of the thighs showed no calcification.

Creatinine Kinase was normal at 199.1 U/L (39 - 308). LDH was elevated at 259.1 $\mathrm{U} / \mathrm{L}(135.0$ - $225 \mathrm{IU} / \mathrm{L})$.

Muscle biopsy reported skeletal muscle interspersed by areas of fibrosis. There were foci of lymphocytes and plasma cells in those areas. Occassional giant cells and poorly formed granulomas were also seen.

Treatment with flexion-extension exercises in conjuction with the physiotherapy unit is ongoing presently. 


\section{Discussion}

Sickle cell disease is the most frequently seen inherited haematological disorder of man. It is made up of a host of genetic disorders characterized by presence of haemoglobin $S$ (Hb-S) which results from substitution of valine for glutamic acid at codon 6 of the beta globin chain gene on chromosome 11 [4]. The disease presents with repeated vaso-occlusive crises (VOC) with complications affecting various systems with an early mortality traceable to pulmonary complications and sepsis. The musculoskeletal system is commonly affected manifesting itself as bone infarction, femoral head osteonecrosis, osteomyelitis and myonecrosis, myofibrosis and fasciitis [4]. A study quoted the prevalence of this to be as high as $54.1 \%$ [7]. Muscle-cell injury occurs secondary to ischeamia from the sickling of red blood cells manifesting as proximal muscle pain, swelling, myonecrosis and myofibrosis with variable inflammatory reaction and collagen deposition, followed by muscle induration, atrophy and contractures [8].

Most patients are young adults and male, with homozygous sickle disease and history of previously treated pain crises. This pain of muscle cell injury is out of proportion and different in character when compared to usual pain crises, reflecting a need for careful history gathering.

A rise in serum CPK and LDH as markers of muscle cell injury is diagnostic but caution needs to be applied in interpreting the results as CPK levels are normal in three reported cases.

MRI shows an increased signal intensity on T2 weighed images because necrosis of myocytes causes an alteration in muscle size and shape, and gadolinium enhancement [9]. MRI was ordered for in this patient but was not done as his relations could not afford it

Involvement of a physical therapist is crucial in preventing disabling sequlae.

\section{Conclusion}

Myofibrosis is a rarely diagnosed complication of sickle cell anaemia with catastrophic consequences for the patient if left unattended to. There is a need to develop a high index suspicion in patients with vaso-oclusive crises in a population at risk for this condition and develop optimal and effective treatment protocols for its management.

\section{Conflict of Interest}

The authors declare no conflicts of interest.

\section{References}

[1] Tageja, N., Racovan, M., Valent, J. and Zonder, J. (2010) Myonecrosis in Sickle Cell Aneamia-Overlooked and Underdiagnosed. Case Reports in Medicine, 2010, Article ID: 659031.

[2] Ham, T.H. and Castle, W.B. (1940) Relationship of Increased Hypotonic Fragility and of Erythrostasis to the Mechanism of Haemolysis in Certain Anaemias. Transactions of the Association of American Physicians, 55, 127-132.

[3] Cai, H. and Harrison, D.G. (2000) Endothelial Dysfunction in Cardiovascular Diseases: The 
Role of Oxidant Stress. Circulation Research, 87, 840-844.

http://dx.doi.org/10.1161/01.RES.87.10.840

[4] Meshikhes, A.-W.N. (1999) Orthopaedic Complications in Sickle Cell Disease. Bahrain Medical Bulletin, 21.

[5] Vicari, P., Achkar, R., Oliveira, R.B., et al. (2004) Myonecrosis in Sickle Cell Aneamia: Case Report and Review of the Literature. Southern Medical Journal, 97, 894-896.

http://dx.doi.org/10.1097/01.SMJ.0000125172.95454.B7

[6] Dorwat, B.B. and Gabuzda, T.G. (2015) Symmetric Myositis and Fasciitis: A Complication of Sickle Cell Aneamia during Vasocclusion. J Rheimatology 1985: 12: 590-5 of Hospital Based Records (1991-2000) in Two Nigerian Hospitals. International Journal of Contemporary Paediatrics, 2, 329-334.

[7] Aliyu, S.U., Rufai'l, A.A. and Jajere, A.M. Musculoskeletal Complications in Sickle Cell Anaemic Patients: A Ten-Year Retrospective Review.

[8] Valeriano-Marcet, J. and Kerr, L.D. (1991) Myonecrosis and Myofibrosis as Complications of Sickle Cell Aneamia. Annals of Internal Medicine, 115, 99-101. http://dx.doi.org/10.7326/0003-4819-115-2-99

[9] May, D.A., Disler, D.G., Jones, E.A., Balkissoon, A.A. and Manaster, B.J. (2000) Abnormal Signal Intensity in Skeletal Muscle at MR Imaging: Patterns, Pearls, and Pitfalls. Radioraphics, 20, S295-S315. http://dx.doi.org/10.1148/radiographics.20.suppl_1.g00oc18s295

Submit or recommend next manuscript to SCIRP and we will provide best service for you:

Accepting pre-submission inquiries through Email, Facebook, LinkedIn, Twitter, etc.

A wide selection of journals (inclusive of 9 subjects, more than 200 journals)

Providing 24-hour high-quality service

User-friendly online submission system

Fair and swift peer-review system

Efficient typesetting and proofreading procedure

Display of the result of downloads and visits, as well as the number of cited articles

Maximum dissemination of your research work

Submit your manuscript at: http://papersubmission.scirp.org/

Or contact ojo@scirp.org 